\title{
Human induced pluripotent stem cells-from mechanisms to clinical applications
}

\author{
Katharina Drews • Justyna Jozefczuk • \\ Alessandro Prigione • James Adjaye
}

Received: 7 March 2012 / Revised: 3 May 2012 / Accepted: 6 May 2012 /Published online: 30 May 2012

(C) Springer-Verlag 2012

\begin{abstract}
Human pluripotent stem cells hold great promise for basic research and regenerative medicine due to their inherent property to propagate infinitely, while maintaining the potential to differentiate into any given cell type of the human body. Since the first derivation in 1998, pluripotent human embryonic stem cells (ESCs) have been studied intensively, and although these cells provoke ethical and immune rejection concerns, translation of human ESC research into the clinics has been initiated. The generation of embryonic stem cell-like human induced pluripotent stem cells (iPSCs) from somatic cells by virus-mediated overexpression of distinct sets of reprogramming factors (OCT4, SOX2, KLF4, and c-MYC, or OCT4, SOX2, NANOG, and LIN28) in 2007 has opened up further opportunities in the field. While circumventing the major disputes associated with human ESCs, iPSCs offer the same advantages and, in addition, new perspectives for personalized
\end{abstract}

$\mathrm{K}$. Drews $\cdot$ J. Jozefczuk $\cdot$ A. Prigione $\cdot$ J. Adjaye $(\bowtie)$

Molecular Embryology and Aging Group,

Department of Vertebrate Genomics,

Max Planck Institute for Molecular Genetics,

Ihnestr. 63-73,

14195 Berlin, Germany

e-mail: adjaye@molgen.mpg.de

URL: http://www.molgen.mpg.de/ molemb/

\section{K. Drews}

Department of Biology, Chemistry and Pharmacy,

Freie Universität Berlin,

Takustr. 3,

14195 Berlin, Germany

\section{J. Adjaye}

Institute for Stem Cell Research and Regenerative Medicine,

Heinrich Heine University Duesseldorf,

Moorenstr. 5,

40225 Duesseldorf, Germany medicine. This review summarizes technical advances toward the generation of potentially clinically relevant human iPSCs. We also highlight key molecular events underlying the process of cellular reprogramming and discuss inherent features of iPSCs, including genome instability and epigenetic memory. Furthermore, we will give an overview of particular envisaged human iPSC applications and point out which improvements are yet to come and what has been achieved so far.

Keywords Human induced pluripotent stem cells · iPSCs · Human embryonic stem cells · ESCs · Mechanisms ·

Applications

\section{Introduction}

Human pluripotent stem cells, which have the ability to selfrenew indefinitely and to form derivatives of all three embryonic germ layers, are of great value for basic research and potential applications in the clinics. Besides teratomaderived embryonal carcinoma cells and embryonic germ cells, biomedical research has focused on human embryonic stem cells (ESCs) as the gold standard of human pluripotent stem cells ever since their derivation by Thomson et al. in 1998 [1]. However, ethical as well as immune rejection concerns are two major issues associated with the utilization of human ESCs in basic and translational research. These conflicts were overcome with the groundbreaking achievement of generating human induced pluripotent stem cells (iPSCs), which are pluripotent stem cells derived from somatic cells mediated by the ectopic expression of four transcription factors, namely OCT4, SOX2, KLF4, and cMYC [2], or OCT4, SOX2, NANOG, and LIN28 [3]. This review briefly summarizes the recent technical progress that 
has been made regarding the generation of human iPSCs, highlights key molecular mechanisms underlying and associated with the process of cellular reprogramming, and illustrates areas of potential applications of human iPSCs emphasizing their value for personalized medicine (Fig. 1).

\section{Generation and mechanisms}

Techniques to generate human iPSCs

Since the first generation of human iPSCs, retro- or lentiviral overexpression of the reprogramming factors has proven to be a robust and efficient way of inducing pluripotency in somatic cells. Efforts have been made to reduce or avoid integration of foreign DNA into the target cells' genomes in order to minimize unpredictable effects of random integrations. To this end, both the identification of small molecules, which enhance the efficiency of cellular reprogramming, and the use of different somatic cell types at distinct developmental stages as starting material have facilitated the reduction of the number of integrating vectors required to induce pluripotency. Valproic acid (VPA), a histone deacetylase inhibitor, for instance, has been shown to increase the efficiency of three factor-mediated reprogramming (OCT4, SOX2, KLF4) and facilitated the generation of human iPSCs by only two factors, namely OCT4 and SOX2 [4]. Furthermore, VPA in combination with 8-bromoadenosine 3', 5'-cyclic monophosphate (8-Br-cAMP), an analog of cyclic AMP, enhanced the induction of pluripotency in human fibroblast cells [5]. Interestingly, vitamin $C$ also mediated the generation of human iPSCs with greater efficiency [6]. Similarly, combined small molecule-based modification of distinct signaling pathways involved in the reprogramming process has been shown to greatly increase the efficiency of reprogramming using fewer reprogramming factors on distinct cell types. This is particularly interesting as supplementation with single molecules may not be

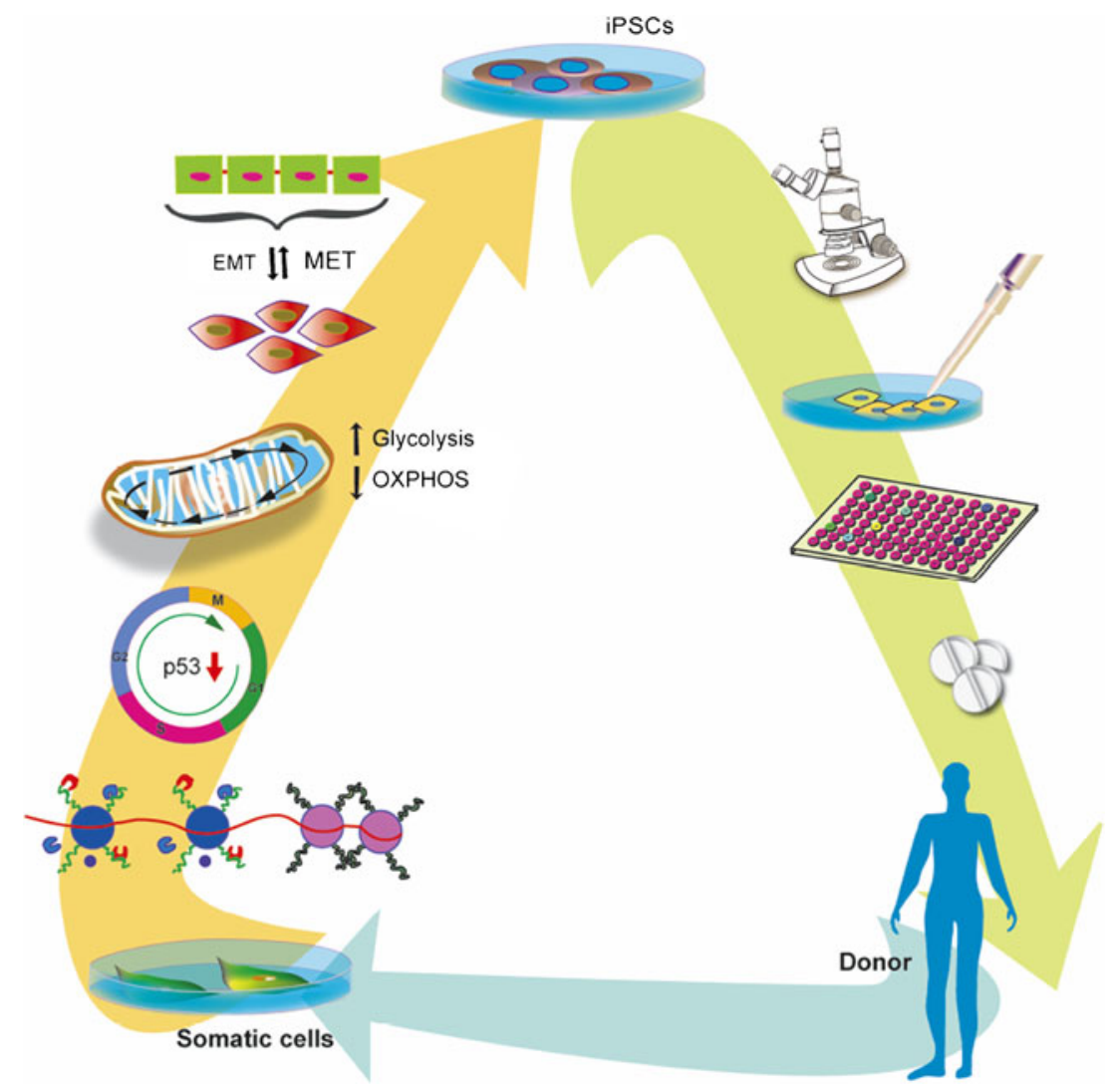

Fig. 1 Hallmarks of cellular reprogramming and applications of human iPSCs. Somatic cells obtained from any given donor can be reprogrammed to iPSCs using a number of different techniques. Key molecular events that mark this de-differentiation process include global chromatin remodeling, circumvention of $\mathrm{p} 53$-induced cell cycle arrest, reprogramming of mitochondria and, in close context, the energy metabolism toward increased glycolysis and decreased mitochondrial oxidative phosphorylation (OXPHOS), and the process of mesenchymal-to-epithelial transition (MET). Once human iPSCs lines from healthy or diseased individuals have been established and fully characterized, they offer unprecedented opportunities in personalized regenerative medicine. Human iPSCs are valuable tools for studying early developmental processes, to model human diseases in a dish, thereby enabling the identification of new diagnostic markers and tools and potential new drug targets, and to perform large-scale toxicity and drug screens upon differentiation into other appropriate cell types. Eventually, human iPSCs are envisaged to directly treat a particular condition of the donor through cellular replacement therapy, if needed, by transplantation of genetically corrected autologous cells 
as efficient as the simultaneous addition of several chemicals [7]. To this end, transient treatment with defined cocktails including, for instance, the ALK4/5/7 inhibitors SB431542 and A-83-01, the MEK inhibitor PD0325901, the GSK-3 inhibitor CHIR99021, the inhibitor of lysine-specific demethylase 1 Parnate (also known as tranylcypromine), the allosteric activator of 3'-phosphoinositide-dependent kinase-1 (PDK1) PS48, the histone deacetylase inhibitor sodium butyrate $(\mathrm{NaB})$, thiazovivin, p160 Rho-associated coiled-coil kinase (ROCK) inhibitor HA-100, and human leukemia inhibitory factor could enhance distinct reprogramming protocols in various somatic cell types, e.g., induction of pluripotency in keratinocytes by overexpression of only OCT4 [7-10]. An alternative approach for reducing the number of genomic integrations includes the development of single vectors, which encode all necessary reprogramming factors and that could potentially be excised from the iPSCs' genomes following acquisition of the fully reprogrammed embryonic stem cell-like state [11-14]. To date, the generation of genetically unmodified human iPSCs has been mediated by transduction of non-integrating adenoviruses [15] or RNA-based Sendai viruses [16], repeated transfection of expression plasmids [17] or repeated electroporation of episomal plasmids [9, 18] or so-called mini circle DNA [19], all of which encode the required reprogramming factors. In contrast to these approaches, Kim et al. treated neonatal fibroblasts with recombinant versions of the reprogramming factor proteins to induce pluripotency [20]; however, this approach was very inefficient. The most recent strategies to de-differentiate human somatic cells included repeated transfection of reprogramming factor-encoding, synthetically modified mRNAs [21] and overexpression of human embryonic stem cell-specific miRNAs, either by lentiviral transduction [22] or by transfection of cocktails of mature miRNAs [23]. However, reproducing studies have yet to be published. A critical review of the in vitro derived mRNA-based reprogramming protocol has revealed major obstacles that need to be addressed before this technique becomes routinely applicable for successful cellular reprogramming [24].

As a result of the combined efforts to efficiently generate pluripotent cells, while avoiding genomic alterations, a wide range of human somatic cells have been reprogrammed, including melanocytes [25]; cord blood-derived cells [9, 26, 27]; adult peripheral blood cells [26, 28, 29]; cells obtained from adipose tissue $[6,9,23,30]$; hepatocytes [31], and amniotic fluid [10, 32-34]; and chorionic villi-derived cells [34] amongst others.

Molecular events underlying cellular reprogramming

Despite a basic understanding of the OCT4, SOX2, NANOG-regulated transcriptional regulatory network that shapes the undifferentiated human pluripotent stem cell identity [35-37], our knowledge of distinct pathways and mechanisms involved in the conversion of the somatic into the pluripotent phenotype is limited. We, therefore, in a recent study analyzed early events triggered by retroviral transduction of the reprogramming factors OCT4, SOX2, $\mathrm{KLF} 4$, and c-MYC - the original method that has proven to be very robust with respect to inducing pluripotency in somatic cells. One of the key findings was that, levels of reactive oxygen species (ROS) increased significantly upon viral transduction, leading to DNA damage and ultimately to the activation of $\mathrm{p} 53$, which is responsible for arresting cell cycle and inducing apoptosis and senescence. Hence, we found transcripts involved in apoptosis, cell cycle regulation, and aging to be over-represented [38]. These findings are in line with the observations that direct or indirect, stable or transient downregulation of p53 enhances cellular reprogramming in mouse and human somatic cells [5, 39-44]. Hence, overcoming this hurdle is a crucial step in acquiring a pluripotent state.

Furthermore, suppression of the epithelial-to-mesenchymal transition and promotion of the reverse process, the mesenchymal-to-epithelial transition (MET), have been shown to be another critical step in the process of cellular reprogramming of mouse cells of mesenchyme origin [45-47]. Likewise, in a meta-analysis, we identified the initiation of MET as an early reprogramming event in human fibroblasts [38] eventually resulting in the establishment of the epithelial ESC-like phenotype characterized by multiple cell-cell adhesion complexes [48-50]. This is also supported by the ameliorating effect of TGF $\beta$ pathway and GSK3 inhibitors on cellular reprogramming [7-10].

Especially in order to enable access of the transcription machinery to pluripotency-associated genes and, thus, for the major transcriptional changes to occur in the process of reprogramming, epigenetic remodeling through distinct alteration of histone modification and $\mathrm{CpG}$ methylation patterns is required as highlighted in the first report of human iPSCs [2]. Global studies based on mouse embryonic fibroblasts (MEFs) and MEF-derived iPSCs unveiled greater details about the kinetics of distinct histone modifications that occur throughout the de-differentiation process [51]. Again, these findings are in line with the observation that treatment of somatic cells with agents, which influence the chromatin remodeling machinery, such as VPA, sodium butyrate, or vitamin $\mathrm{C}$, following overexpression of the reprogramming factors increases reprogramming efficiencies $[4,6,10]$.

Reprogramming of mitochondria and energy metabolism

Reprogramming of energy metabolism is a known feature of cancer cells [52]. As cancer cells proliferate, there appears to 
be a switch from mitochondrial-based oxidative phosphorylation to glycolysis even in the presence of oxygen, a phenomenon referred to as the Warburg effect [53]. This was initially thought to be due to damage to mitochondria while more recent findings suggest that the reason for this switch lies in the change of energy requirement and anabolic demands of tumor cells [54]. In fact, cancer cells exhibit a high necessity of building the macromolecules needed to proliferate while avoiding the generation of high levels of ROS, a common by-product of mitochondrial respiration. Hence, cancer cells opt for re-routing the energy flux outside the organelle.

A similar mechanism may also be in place during reprogramming. Recent findings from our group $[55,56]$ and from others [10, 57-62] suggest, indeed, that the derivation of iPSCs is associated with a reconfiguration of mitochondria and bioenergetic metabolism. Mitochondria within iPSCs exhibit a reduction in number $[55,57,59,60]$ and oxidative phosphorylation, which then translates into increased glycolysis [55, 56, 58, 61, 62] and lower production of ROS [55, 57, 63]. Interestingly, these metabolic changes may play an instrumental role in reprogramming, as they occur before the re-establishment of the human ESC-like properties [58]. Accordingly, the modulation of oxygen levels and the small molecule-based alteration of energy metabolism have been found capable of significantly enhancing the efficiency of cellular reprogramming [10,64].

\section{Genomic instability}

Recent findings have pointed out that the derivation of iPSCs alters the integrity of the genomes of the parental cells. The occurrence of chromosomal aberrations within human ESCs and iPSCs has been demonstrated by different groups $[65,66]$, as the reprogramming process has been found to be associated with a high mutation rate [67-69]. Certain types of aneuploidies within human ESCs and iPSCs may induce proliferative advantage by increasing the expression of pluripotency-associated genes. Accordingly, the affected chromosomes have been found to harbor genes such as NANOG, LIN28, or LEFTY [65, 66]. Additionally, we recently demonstrated that the mitochondrial genome might also undergo mutational events [63].

This is a highly relevant issue as genome integrity is of critical importance for iPSC-based clinical applications. Hence, it is essential to address the biological and clinical relevance of these mutations. Reassuringly, the detected chromosomal abnormalities have so far not been linked with a functional defect. Indeed, genomic aberrations have been suggested to be transient as they do not compromise cellular functionality [69]. It has also been demonstrated that several iPSC lines harboring karyotype variations could pass a stringent test of differentiation capacity [70]. In accordance, we observed that, although aged-derived iPSCs exhibited numerous chromosomal aberrations, the cells showed low levels of oxidative stress and DNA damage, in a similar manner as iPSCs derived from young donors and human ESCs, and did not exhibit apoptosis resistance, which are all hallmarks of cancer transformation [63]. Finally, the presence of mitochondrial mutational events did not affect the reprogramming-associated modulation of mitochondria and energy metabolism [56].

Taken together, despite the potential risks for iPSC-based clinical applications, the detected loss of nuclear and mitochondrial genome integrity has not been associated with any specific cellular deficiency, suggesting that reprogrammingrelated genomic alterations might not necessarily translate in the acquirement of malignant features. Nevertheless, further in-depth investigations are warranted to distinguish harmless variations from those impairing the functionality or promoting clinical risks [71].

\section{Epigenetic memory}

With the progress of the iPSC field, an increasing number of human and murine somatic cell types have been reprogrammed to a pluripotent state enabling studies to evaluate basic pluripotent stem cell properties among iPSCs derived from different origins and by different techniques and also with respect to human ESCs. One of the early, comparative studies of that kind was based on global gene expression, miRNA expression, and histone modification data, amongst others; this revealed that distinct molecular signatures are characteristic for iPSCs from certain tissues of origin (although derived from different species) and distinguished iPSCs from ESCs [72]. Kim et al. were able to identify and link DNA methylation patterns of murine and human iPSCs from different tissues to their characteristic differentiation behavior but noticed diminution of these marks, at least in mouse iPSCs, by repeated rounds of reprogramming and chromatin-modifying chemicals [73, 74]. Similarly, Polo et al. were able to correlate patterns of chromatin modification with distinct expression signatures and differentiation properties using a system of mouse so-called secondary iPSCs [75]. For human iPSCs, different reports have highlighted the existence of residual gene expression patterns in distinct iPSCs, which may result from incomplete promoter DNA methylation of tissue-specific genes and which also distinguish them from human ESCs, even if non-integrating reprogramming methods were used; it was also shown that these iPSCs preferably differentiate back into the lineage they were originally derived from [31, 33, 76-78]. This inherent characteristic of iPSCs can be exploited in the sense that if donor cells of mesoderm origin (e.g., cardiomyocytes and adipocytes) are needed for downstream applications, one should use cells of mesoderm origin (bone marrow-derived MSCs) as the source for reprogramming into iPSCs. A precedence for this is the derivation of iPSCs 
from retinal pigmented cells and the rapid and efficient differentiation of these back to the original cell type [77].

In contrast, Guenther et al. argued against the existence of an epigenetic memory following a meta-analysis of transcriptional and histone modification data [79]. They suggested that the slight differences observed were primarily due to laboratory-specific bias rather than fundamental differences between different types of human iPSCs and iPSCs and ESCs. In summary, the question if iPSCs retain an epigenetic memory throughout the process of de-differentiation and whether they are to be distinguished from human ESCs as a separate pluripotent cell type is still a matter of debate, which will be clarified as research proceeds.

\section{Clinical applications}

Modeling human diseases in a dish

The successful conversion of human fibroblasts into induced pluripotent stem cells has opened up new opportunities for modeling human diseases. The iPSC technology has provided a unique possibility to investigate molecular mechanisms underlying the etiology of many diseases in vitro.

Within the last few years, several disease models have been generated and affirmed that iPSCs enable to reconstruct a disease phenotype in vitro. In Table 1, we present a list of selected published disease models, for which iPSCderived somatic cells have been shown to possess the disease phenotype or which have been used for drug screens or other functional studies. Definitely, it is a very demanding task to indeed prove that the models convey the features of the disease. It is necessary to recruit a reasonable amount of patients, generate many iPSC lines, and efficiently differentiate iPSCs into the disease-affected cell type. However, it is worthwhile, because once generated, "disease in a dish" provides an extraordinary opportunity to find novel diagnostic markers and tools, to identify drug targets, and to screen for novel compounds that can treat the disease of interest. For several disease models including spinal muscular atrophy (SMA) [80] and Rett's syndrome [81], it has been successfully demonstrated that in vitro drug treatment restores normal distribution of affected protein.

\section{Human iPSCs as a tool for toxicology studies}

The main funds of pharmaceutical companies are spent on screening for metabolic properties early in drug discovery processes [82]. The implementation of human iPSCs will significantly simplify this procedure as unpredicted human metabolism is one of the main causes of the withdrawal of potential new drugs from pharmaceutical projects. Principally, any cell type existing today does not copy the complexity and function of the liver. The human models available to date are utilizing cancer cell lines or primary cells isolated from liver biopsies; unfortunately, these two cell types possess significant limitations [83, 84]. Primary human hepatocytes are currently used as the gold standard in drug metabolism studies even though they lose functional properties when maintained in vitro. In general, there is an immense requirement for in vitro models of healthy and disease-specific hepatocytes. Hepatocytes and cardiomyocytes are the most susceptible to drug-induced damage (toxicity). It is very difficult to precisely predict hepatotoxic and cardiotoxic properties of new compounds in humans, and in many cases, toxicity is observed only in the late phases of clinical trials, due to the species-specific differences and extensive use of animal models. Although significant progress has been made in differentiating iPSCs cells into cardiomyocytes [85, 86] and hepatocytes [87-90], still, efficient generation of a pure and mature cell population has not yet been accomplished. Undoubtedly, the standardization of the production of functional human cells is needed, only then iPSC-derived hepatocytes, cardiomyocytes, neurons, and other cell types will significantly improve the in vitro metabolism studies and toxicity trials.

\section{Therapeutic potential of human iPSCs}

The generation of patient-specific pluripotent stem cells has been one of the major goals in the field of regenerative medicine. Differentiation of iPSCs into a distinct cell types is of prime importance, simply because access to a large number of cells would allow their use instead of whole organ transplantation. As iPSCs are explored as a source for generating unlimited amounts of patient-specific cells for transplantation, it is very important to precisely understand the developmental processes that guide the maturation of the specific cell fate and, thereby, help to repeat these events in vitro and engineer artificial cells and tissues. In theory, human iPSCs could be applied to treat a wide range of human diseases.

The in vitro developmental potential and the success of iPSCs in animal models [91, 92] reveal the principle of using human iPSC-derived cells as a regenerative source for transplantation therapies. In this respect, the first clinical trials using human ESC-derived cells will lay the foundation for future clinical applications of iPSCs. Recently, the company Advanced Cell Technology undertook a cell replacement trial to assess the safety of treating macular dystrophy by transplantation of human ESC-derived retinal pigment cells [93]. Despite the initial success in this trial, the "cows are yet to come home," and most importantly, it is too soon to exclude the emergence of long-term effects in these patients. Despite this hopeful human ESCs-based trial in the eye, which is an immune-privileged organ, many general and experimental obstacles must be solved before specified 
Table 1 Examples of successful iPSC-based modeling of complex disorders in a dish

\begin{tabular}{llll}
\hline Disease name & $\begin{array}{l}\text { Molecular } \\
\text { defect }\end{array}$ & Cells derived from iPSCs & $\begin{array}{l}\text { Phenotype in } \\
\text { iPSC-derived } \\
\text { cells }\end{array}$ \\
\hline
\end{tabular}

\section{Ectoderm}

Spinal muscular atrophy

(SMA) [80]

Parkinson's disease [106-109]

Parkinson's disease

(idiopathic and familial) [110]

Rett's syndrome [111, 112]

Mucopolysaccharidosis type

IIIB [113]

Schizophrenia [114]

X-linked adrenoleukodystrophy

(X-ALD), childhood cerebral

ALD (CCALD), and

adrenomyeloneuropathy

(AMN) [115]

Retinitis pigmentosa [116]

\author{
Alzheimer's disease \\ (familial and sporadic) [117] \\ Mesoderm
}

Fanconi's anemia [118]

LEOPARD syndrome [119]

Type 1 long QT syndrome [120]

Type 2 long QT syndrome [121]

Recessive dystrophic

epidermolysis bullosa

(RDEB) [123]

Familial dilated

cardiomyopathy [123]

Huntington disease [124]

\section{Endoderm}

Glycogen storage disease Ia (GSD1a) [125, 89]

Familial

hypercholesterolemia [89]

Wilson's disease [126]

Hepatitis C [127]

Mutations in SMN1
Mutation in LRRK2
and/or SNCA

Mutation in LRRK2

Mutation in $M E C P 2$

Mutation in $N A G L U$

Complex trait

Mutation in $A B C D 1$

$$
\begin{aligned}
& \text { Mutations in } R P 9 \text {, } \\
& \text { RP1, PRPH2, } \\
& \text { or } R H O
\end{aligned}
$$

APP duplication

$F A A$ and FAD2

Mutation in PTPN11

Mutation in $K C N Q 1$

Mutation in $\mathrm{KCNH} 2$

Mutation in $C O L 7 A 1$

Mutation in TNNT2

Expansion of a CAG trinucleotide repeat in $H T T$

Mutation in glucose6-phosphat-transporter gene or absent hepatic glucose-6phosphatase enzyme Mutation in

LDLR

Mutation in $A T P 7 B$

Hepatitis $\mathrm{C}$ virus (HCV) infection

\section{Astrocytes, neurons, mature motor neurons \\ Dopaminergic neurons}

Ventral midbrain dopaminergic neurons Neural progenitor cells

Differentiated neurons and neural stem cells Neurons

Neurons, oligodendrocytes

Photoreceptor precursors, retinal-pigment epithelial cells, rod photoreceptor cells, retinal progenitors

Neurons

Hematopoietic cells

Cardiomyocytes

Cardiomyocytes

Cardiomyocytes

Hematopoietic and non-hematopoietic cells

Cardiomyocytes

Neurons

Hepatocyte-like cells (fetal)

Hepatocyte-like cells (fetal)

Hepatocyte-like cells

Hepatocyte-like cells infected with genotype 2a HCV
Yes

No

Yes

No

Yes (impaired

autophagy)

Yes

Partially

Yes

Partially

Yes

Yes

No (rescued)

Yes

Yes

Yes

Partially

Partially

Partially (increased lysosomal activity)

\section{Ascorbic acid, a-tocopherol, b-carotene}

$\beta$-Secretase inhibitors

No

No

No

Nifedipine, E-4031, pinacidil, ranolazine, cisapride

Gene correction with Col7a1

Metoprolol, overexpression of Serca2a

No

(n)

No

Yes

Gene correction with $A T P 7 B$, curcumin

Yes

Cells supported the HCV life cycle, appropriate antiviral inflammatory response 
Table 1 (continued)

\begin{tabular}{|c|c|c|c|c|}
\hline Disease name & $\begin{array}{l}\text { Molecular } \\
\text { defect }\end{array}$ & Cells derived from iPSCs & $\begin{array}{l}\text { Phenotype in } \\
\text { iPSC-derived } \\
\text { cells }\end{array}$ & Drug or functional tests \\
\hline A1AT deficiency [128] & Mutation in $A 1 A T$ & Hepatocyte-like cells & Yes (corrected) & $\begin{array}{l}\text { Transplanted into } \\
\text { mice with liver } \\
\text { injury }\end{array}$ \\
\hline \multicolumn{5}{|l|}{ Several germ layers } \\
\hline Down's syndrome [107] & Trisomy 21 & Teratoma & Yes & No \\
\hline Familial dysautonomia [129] & Mutation in $I K B K A P$ & $\begin{array}{l}\text { Hematopoietic cells, endothelial } \\
\text { cells, central nervous system } \\
\text { and peripheral neurons, } \\
\text { endodermal cells }\end{array}$ & Yes & Kinetin \\
\hline $\begin{array}{l}\text { Friedreich's ataxia } \\
\text { (FRDA) [130] }\end{array}$ & $\begin{array}{l}\text { GAA repeat in } \\
F X N\end{array}$ & $\begin{array}{l}\text { Cardiomyocytes, } \\
\text { peripheral neurons }\end{array}$ & Partially & No \\
\hline
\end{tabular}

$A 1 A T \alpha$-1-antitrypsin; $A B C D 1$ ATP-binding cassette, subfamily D, member 1 ; $A P P$ amyloid- $\beta$ precursor protein; $A T P 7 B$ copper-transporting ATPase 2; CFTR cystic fibrosis transmembrane conductance regulator; COL7A1 $\alpha 1$-chain of type VII collagen; FAA Fanconi's anemia, complementation group A; FAD2 Fanconi's anemia, complementation group D2; FXN frataxin; HCV hepatitis C virus; HTT huntingtin; IGF1 insulin-like growth factor 1 ; IKBKAP I-K-B kinase complex-associated protein; $K C N H 2$ potassium voltage-gated channel, subfamily $\mathrm{H}$ (eagrelated), member 2; KCNQ1 potassium voltage-gated channel; $L D L R$ low-density lipoprotein receptor; $L R R K 2$ leucine-rich repeat kinase 2; $M E C P 2$ methyl CpG binding protein 2; NAGLU $\alpha$-N-acetylglucosaminidase; PRPH2 peripherin 2; PTPN11 protein tyrosine phosphatase, nonreceptor type 11; RHO rhodopsin; RP retinitis pigmentosa; Serca2a sarcoplasmic/endoplasmic reticulum calcium ATPase 2; SMN1 survival of motor neuron 1; SNCA $\alpha$-synuclein; TNNT2 troponin T type 2; VPA valproic acid

cell types derived from iPSCs can be applied to humans. First, provision of personalized medicine in the form of patient-specific iPSC-derived cellular therapeutics is very promising but costly. To compromise on time and high costs for the generation, characterization, and safety validation of individual clinical-grade iPSC lines on the one hand and possible immune rejection of non-autologous transplants on the other, the establishment of HLA-haplotype banks of iPSCs has been suggested [94, 95]. Associated with that, however, are the low cloning efficiency and poor survival of human pluripotent stem cells following cryopreservation [96]. Although an improvement of both aspects has been reported for the supplementation of culture media with ROCK inhibitors, such as Y-27632 [97-99], there is room for further optimization of pluripotent stem cell cryopreservation protocols. Second, standards of defined, xeno-free human iPSC culture, differentiation, and cryopreservation conditions, i.e., feeder-free culture or maintenance on autologous feeders [100] in media devoid of non-human components, have to be uniformly applied [101, 102]. Third, it is crucial that we develop an efficient alternative approach to viral reprogramming and to understanding the genetic and epigenetic changes that take place during this process. Furthermore, the risk of teratoma formation, toxicity, and immunological rejection should be eliminated. Moreover, protocols for efficient and reproducible derivation of fully matured cells from iPSCs and purification of defined cell lineages should be optimized.
In summary, although hurdles remain to be overcome before the iPSC technology can be routinely applied in in vitro disease studies, drug development, toxicity tests, and cellular replacement therapies, major progress has been made. Generally, technologies to derive footprint-free human iPSCs have been established. Numerous diseasespecific iPSC lines have been derived, and differentiation protocols to generate terminally differentiated cells of interest have been developed. CELLular Dynamics International, for example, set new standards offering a variety of iPSCderived terminally differentiated cell types, e.g., cardiomyocytes, hepatocytes, and neuronal cells, which are useful for studying molecular mechanisms underlying distinct diseases, assessing safety and efficacy of potential new drugs, and evaluating toxicity in vitro [103-105]. Furthermore, a lot will be learned from the first ongoing and proposed clinical trials involving human ESC-derived cell products, which will be transferable to human iPSCs in the future.

Acknowledgments We are particularly grateful to Monica Shevack for preparing the graphical overview. The authors acknowledge support from the Max Planck Society. James Adjaye acknowledges support from the German Federal Ministry of Education and Research (BMBF) grants (01GN0807) and (0315717A), which is a partner of the ERASysBio+ initiative supported under the EU ERA-NET Plus scheme in FP7. Alessandro Prigione acknowledges the Fritz Thyssen Foundation.

Disclosure statement The authors of this manuscript have nothing to declare. 


\section{References}

1. Thomson JA, Itskovitz-Eldor J, Shapiro SS, Waknitz MA, Swiergiel JJ, Marshall VS, Jones JM (1998) Embryonic stem cell lines derived from human blastocysts. Science 282:1145-1147

2. Takahashi K, Tanabe K, Ohnuki M, Narita M, Ichisaka T, Tomoda K, Yamanaka S (2007) Induction of pluripotent stem cells from adult human fibroblasts by defined factors. Cell 131:861-872

3. Yu J, Vodyanik MA, Smuga-Otto K, Antosiewicz-Bourget J, Frane JL, Tian S, Nie J, Jonsdottir GA, Ruotti V, Stewart R et al (2007) Induced pluripotent stem cell lines derived from human somatic cells. Science 318:1917-1920

4. Huangfu D, Osafune K, Maehr R, Guo W, Eijkelenboom A, Chen S, Muhlestein W, Melton DA (2008) Induction of pluripotent stem cells from primary human fibroblasts with only Oct4 and Sox2. Nat Biotechnol 26:1269-1275

5. Wang Y, Adjaye J (2011) A cyclic AMP analog, 8-Br-cAMP, enhances the induction of pluripotency in human fibroblast cells. Stem Cell Rev 7:331-341

6. Esteban MA, Wang T, Qin B, Yang J, Qin D, Cai J, Li W, Weng Z, Chen J, Ni S et al (2010) Vitamin C enhances the generation of mouse and human induced pluripotent stem cells. Cell Stem Cell 6:71-79

7. Lin T, Ambasudhan R, Yuan X, Li W, Hilcove S, Abujarour R, Lin X, Hahm HS, Hao E, Hayek A et al (2009) A chemical platform for improved induction of human iPSCs. Nat Methods 6:805-808

8. Li W, Zhou H, Abujarour R, Zhu S, Young Joo J, Lin T, Hao E, Scholer HR, Hayek A, Ding S (2009) Generation of humaninduced pluripotent stem cells in the absence of exogenous Sox2. Stem Cells 27:2992-3000

9. Yu J, Chau KF, Vodyanik MA, Jiang J, Jiang Y (2011) Efficient feeder-free episomal reprogramming with small molecules. PLoS One 6:e17557

10. Zhu S, Li W, Zhou H, Wei W, Ambasudhan R, Lin T, Kim J, Zhang K, Ding S (2010) Reprogramming of human primary somatic cells by OCT4 and chemical compounds. Cell Stem Cell 7:651-655

11. Carey BW, Markoulaki S, Hanna J, Saha K, Gao Q, Mitalipova M, Jaenisch R (2009) Reprogramming of murine and human somatic cells using a single polycistronic vector. Proc Natl Acad Sci U S A 106:157-162

12. Kaji K, Norrby K, Paca A, Mileikovsky M, Mohseni P, Woltjen K (2009) Virus-free induction of pluripotency and subsequent excision of reprogramming factors. Nature 458:771-775

13. Somers A, Jean JC, Sommer CA, Omari A, Ford CC, Mills JA, Ying L, Sommer AG, Jean JM, Smith BW et al (2010) Generation of transgene-free lung disease-specific human induced pluripotent stem cells using a single excisable lentiviral stem cell cassette. Stem Cells 28:1728-1740

14. Woltjen K, Michael IP, Mohseni P, Desai R, Mileikovsky M, Hamalainen R, Cowling R, Wang W, Liu P, Gertsenstein M et al (2009) piggyBac transposition reprograms fibroblasts to induced pluripotent stem cells. Nature 458:766-770

15. Zhou W, Freed CR (2009) Adenoviral gene delivery can reprogram human fibroblasts to induced pluripotent stem cells. Stem Cells 27:2667-2674

16. Fusaki N, Ban H, Nishiyama A, Saeki K, Hasegawa M (2009) Efficient induction of transgene-free human pluripotent stem cells using a vector based on Sendai virus, an RNA virus that does not integrate into the host genome. Proc Jpn Acad Ser B Phys Biol Sci 85:348-362

17. Si-Tayeb K, Noto FK, Sepac A, Sedlic F, Bosnjak ZJ, Lough JW, Duncan SA (2010) Generation of human induced pluripotent stem cells by simple transient transfection of plasmid DNA encoding reprogramming factors. BMC Dev Biol 10:81
18. Yu J, Hu K, Smuga-Otto K, Tian S, Stewart R, Slukvin II, Thomson JA (2009) Human induced pluripotent stem cells free of vector and transgene sequences. Science 324:797-801

19. Jia F, Wilson KD, Sun N, Gupta DM, Huang M, Li Z, Panetta NJ, Chen ZY, Robbins RC, Kay MA et al (2010) A nonviral minicircle vector for deriving human iPS cells. Nat Methods 7:197-199

20. Kim D, Kim CH, Moon JI, Chung YG, Chang MY, Han BS, Ko S, Yang E, Cha KY, Lanza R et al (2009) Generation of human induced pluripotent stem cells by direct delivery of reprogramming proteins. Cell Stem Cell 4:472-476

21. Warren L, Manos PD, Ahfeldt T, Loh YH, Li H, Lau F, Ebina W, Mandal PK, Smith ZD, Meissner A et al (2010) Highly efficient reprogramming to pluripotency and directed differentiation of human cells with synthetic modified mRNA. Cell Stem Cell 7:618-630

22. Anokye-Danso F, Trivedi CM, Juhr D, Gupta M, Cui Z, Tian Y, Zhang Y, Yang W, Gruber PJ, Epstein JA et al (2011) Highly efficient miRNA-mediated reprogramming of mouse and human somatic cells to pluripotency. Cell Stem Cell 8:376-388

23. Miyoshi N, Ishii H, Nagano H, Haraguchi N, Dewi DL, Kano Y, Nishikawa S, Tanemura M, Mimori K, Tanaka F et al (2011) Reprogramming of mouse and human cells to pluripotency using mature microRNAs. Cell Stem Cell 8:633-638

24. Drews K, Tavernier G, Demeester J, Lehrach H, De Smedt SC, Rejman J, Adjaye J (2012) The cytotoxic and immunogenic hurdles associated with non-viral mRNA-mediated reprogramming of human fibroblasts. Biomaterials 33(16):4059-4068

25. Utikal J, Maherali N, Kulalert W, Hochedlinger K (2009) Sox2 is dispensable for the reprogramming of melanocytes and melanoma cells into induced pluripotent stem cells. J Cell Sci 122:3502-3510

26. Chou BK, Mali P, Huang X, Ye Z, Dowey SN, Resar LM, Zou C, Zhang YA, Tong J, Cheng L (2011) Efficient human iPS cell derivation by a non-integrating plasmid from blood cells with unique epigenetic and gene expression signatures. Cell Res 21:518-529

27. Haase A, Olmer R, Schwanke K, Wunderlich S, Merkert S, Hess C, Zweigerdt R, Gruh I, Meyer J, Wagner S et al (2009) Generation of induced pluripotent stem cells from human cord blood. Cell Stem Cell 5:434-441

28. Kunisato A, Wakatsuki M, Shinba H, Ota T, Ishida I, Nagao K (2011) Direct generation of induced pluripotent stem cells from human nonmobilized blood. Stem Cells Dev 20:159-168

29. Loh YH, Agarwal S, Park IH, Urbach A, Huo H, Heffner GC, Kim K, Miller JD, Ng K, Daley GQ (2009) Generation of induced pluripotent stem cells from human blood. Blood 113:5476-5479

30. Sun N, Panetta NJ, Gupta DM, Wilson KD, Lee A, Jia F, Hu S, Cherry AM, Robbins RC, Longaker MT et al (2009) Feeder-free derivation of induced pluripotent stem cells from adult human adipose stem cells. Proc Natl Acad Sci U S A 106:15720-15725

31. Ohi Y, Qin H, Hong C, Blouin L, Polo JM, Guo T, Qi Z, Downey SL, Manos PD, Rossi DJ et al (2011) Incomplete DNA methylation underlies a transcriptional memory of somatic cells in human iPS cells. Nat Cell Biol 13:541-549

32. Li C, Zhou J, Shi G, Ma Y, Yang Y, Gu J, Yu H, Jin S, Wei Z, Chen $F$ et al (2009) Pluripotency can be rapidly and efficiently induced in human amniotic fluid-derived cells. Hum Mol Genet $18: 4340-4349$

33. Wolfrum K, Wang Y, Prigione A, Sperling K, Lehrach H, Adjaye J (2010) The LARGE principle of cellular reprogramming: lost, acquired and retained gene expression in foreskin and amniotic fluid-derived human iPS cells. PLoS One 5:e13703

34. Ye L, Chang JC, Lin C, Sun X, Yu J, Kan YW (2009) Induced pluripotent stem cells offer new approach to therapy in thalassemia and sickle cell anemia and option in prenatal diagnosis in genetic diseases. Proc Natl Acad Sci U S A 106:9826-9830

35. Babaie Y, Herwig R, Greber B, Brink TC, Wruck W, Groth D, Lehrach H, Burdon T, Adjaye J (2007) Analysis of Oct4-dependent 
transcriptional networks regulating self-renewal and pluripotency in human embryonic stem cells. Stem Cells 25:500-510

36. Boyer LA, Lee TI, Cole MF, Johnstone SE, Levine SS, Zucker JP, Guenther MG, Kumar RM, Murray HL, Jenner RG et al (2005) Core transcriptional regulatory circuitry in human embryonic stem cells. Cell 122:947-956

37. Jung M, Peterson H, Chavez L, Kahlem P, Lehrach H, Vilo J, Adjaye J (2010) A data integration approach to mapping OCT4 gene regulatory networks operative in embryonic stem cells and embryonal carcinoma cells. PLoS One 5:e10709

38. Mah N, Wang Y, Liao MC, Prigione A, Jozefczuk J, Lichtner B, Wolfrum K, Haltmeier M, Flottmann M, Schaefer M et al (2011) Molecular insights into reprogramming-initiation events mediated by the OSKM gene regulatory network. PLoS One 6:e24351

39. Hong H, Takahashi K, Ichisaka T, Aoi T, Kanagawa O, Nakagawa M, Okita K, Yamanaka S (2009) Suppression of induced pluripotent stem cell generation by the p53-p21 pathway. Nature 460:1132-1135

40. Kawamura T, Suzuki J, Wang YV, Menendez S, Morera LB, Raya A, Wahl GM, Izpisua Belmonte JC (2009) Linking the p53 tumour suppressor pathway to somatic cell reprogramming. Nature 460:1140-1144

41. Li H, Collado M, Villasante A, Strati K, Ortega S, Canamero M, Blasco MA, Serrano M (2009) The Ink4/Arf locus is a barrier for iPS cell reprogramming. Nature 460:1136-1139

42. Marion RM, Strati K, Li H, Murga M, Blanco R, Ortega S, Fernandez-Capetillo O, Serrano M, Blasco MA (2009) A p53mediated DNA damage response limits reprogramming to ensure iPS cell genomic integrity. Nature 460:1149-1153

43. Utikal J, Polo JM, Stadtfeld M, Maherali N, Kulalert W, Walsh RM, Khalil A, Rheinwald JG, Hochedlinger K (2009) Immortalization eliminates a roadblock during cellular reprogramming into iPS cells. Nature 460:1145-1148

44. Zhao Y, Yin X, Qin H, Zhu F, Liu H, Yang W, Zhang Q, Xiang C, Hou P, Song Z et al (2008) Two supporting factors greatly improve the efficiency of human iPSC generation. Cell Stem Cell 3:475-479

45. Li R, Liang J, Ni S, Zhou T, Qing X, Li H, He W, Chen J, Li F, Zhuang Q et al (2010) A mesenchymal-to-epithelial transition initiates and is required for the nuclear reprogramming of mouse fibroblasts. Cell Stem Cell 7:51-63

46. Liao B, Bao X, Liu L, Feng S, Zovoilis A, Liu W, Xue Y, Cai J, Guo X, Qin B et al (2011) MicroRNA cluster 302-367 enhances somatic cell reprogramming by accelerating a mesenchymal-toepithelial transition. J Biol Chem 286:17359-17364

47. Samavarchi-Tehrani P, Golipour A, David L, Sung HK, Beyer TA, Datti A, Woltjen K, Nagy A, Wrana JL (2010) Functional genomics reveals a BMP-driven mesenchymal-to-epithelial transition in the initiation of somatic cell reprogramming. Cell Stem Cell 7:64-77

48. Eastham AM, Spencer H, Soncin F, Ritson S, Merry CL, Stern PL, Ward CM (2007) Epithelial-mesenchymal transition events during human embryonic stem cell differentiation. Cancer Res 67:11254-11262

49. Van Hoof D, Braam SR, Dormeyer W, Ward-van Oostwaard D, Heck AJ, Krijgsveld J, Mummery CL (2008) Feeder-free monolayer cultures of human embryonic stem cells express an epithelial plasma membrane protein profile. Stem Cells 26:2777-2781

50. Wong RC, Pebay A, Nguyen LT, Koh KL, Pera MF (2004) Presence of functional gap junctions in human embryonic stem cells. Stem Cells 22:883-889

51. Mattout A, Biran A, Meshorer E (2011) Global epigenetic changes during somatic cell reprogramming to iPS cells. J Mol Cell Biol 3:341-350

52. Hsu PP, Sabatini DM (2008) Cancer cell metabolism: Warburg and beyond. Cell 134:703-707
53. Warburg O (1956) On the origin of cancer cells. Science 123:309-314

54. Vander Heiden MG, Cantley LC, Thompson CB (2009) Understanding the Warburg effect: the metabolic requirements of cell proliferation. Science 324:1029-1033

55. Prigione A, Fauler B, Lurz R, Lehrach H, Adjaye J (2010) The senescence-related mitochondrial/oxidative stress pathway is repressed in human induced pluripotent stem cells. Stem Cells 28:721-733

56. Prigione A, Lichtner B, Kuhl H, Struys EA, Wamelink M, Lehrach H, Ralser M, Timmermann B, Adjaye J (2011) Human iPSCs harbor homoplasmic and heteroplasmic mitochondrial DNA mutations while maintaining hESC-like metabolic reprogramming. Stem Cells 29(9):1338-1348

57. Armstrong L, Tilgner K, Saretzki G, Atkinson SP, Stojkovic M, Moreno R, Przyborski S, Lako M (2010) Human induced pluripotent stem cell lines show stress defense mechanisms and mitochondrial regulation similar to those of human embryonic stem cells. Stem Cells 28:661-673

58. Folmes CD, Nelson TJ, Martinez-Fernandez A, Arrell DK, Lindor JZ, Dzeja PP, Ikeda Y, Perez-Terzic C, Terzic A (2011) Somatic oxidative bioenergetics transitions into pluripotency-dependent glycolysis to facilitate nuclear reprogramming. Cell Metab $14: 264-271$

59. Kelly RD, Sumer H, McKenzie M, Facucho-Oliveira J, Trounce IA, Verma PJ, St John JC (2011) The effects of nuclear reprogramming on mitochondrial DNA replication. Stem Cell Rev. doi:10.1007/s12015-011-9318-7

60. Suhr ST, Chang EA, Tjong J, Alcasid N, Perkins GA, Goissis MD, Ellisman MH, Perez GI, Cibelli JB (2010) Mitochondrial rejuvenation after induced pluripotency. PLoS One 5:e14095

61. Varum S, Rodrigues AS, Moura MB, Momcilovic O, Easley CAt, Ramalho-Santos J, Van Houten B, Schatten G (2011) Energy metabolism in human pluripotent stem cells and their differentiated counterparts. PLoS One 6:e20914

62. Zhang J, Khvorostov I, Hong JS, Oktay Y, Vergnes L, Nuebel E, Wahjudi PN, Setoguchi K, Wang G, Do A et al (2011) UCP2 regulates energy metabolism and differentiation potential of human pluripotent stem cells. EMBO J 30:4860-4873

63. Prigione A, Hossini AM, Lichtner B, Serin A, Fauler B, Megges M, Lurz R, Lehrach H, Makrantonaki E, Zouboulis CC et al (2011) Mitochondrial-associated cell death mechanisms are reset to an embryonic-like state in aged donor-derived iPS cells harboring chromosomal aberrations. PLoS One 6: e27352

64. Yoshida Y, Takahashi K, Okita K, Ichisaka T, Yamanaka S (2009) Hypoxia enhances the generation of induced pluripotent stem cells. Cell Stem Cell 5:237-241

65. Laurent LC, Ulitsky I, Slavin I, Tran H, Schork A, Morey R, Lynch C, Harness JV, Lee S, Barrero MJ et al (2011) Dynamic changes in the copy number of pluripotency and cell proliferation genes in human ESCs and iPSCs during reprogramming and time in culture. Cell Stem Cell 8:106-118

66. Mayshar Y, Ben-David U, Lavon N, Biancotti JC, Yakir B, Clark AT, Plath K, Lowry WE, Benvenisty N (2010) Identification and classification of chromosomal aberrations in human induced pluripotent stem cells. Cell Stem Cell 7:521-531

67. Gore A, Li Z, Fung HL, Young JE, Agarwal S, AntosiewiczBourget J, Canto I, Giorgetti A, Israel MA, Kiskinis E et al (2011) Somatic coding mutations in human induced pluripotent stem cells. Nature 471:63-67

68. Hussein SM, Batada NN, Vuoristo S, Ching RW, Autio R, Narva E, Ng S, Sourour M, Hamalainen R, Olsson C et al (2011) Copy number variation and selection during reprogramming to pluripotency. Nature 471:58-62 
69. Pasi CE, Dereli-Oz A, Negrini S, Friedli M, Fragola G, Lombardo A, Van Houwe G, Naldini L, Casola S, Testa G et al (2011) Genomic instability in induced stem cells. Cell Death Differ 18:745-753

70. Boulting GL, Kiskinis E, Croft GF, Amoroso MW, Oakley DH, Wainger BJ, Williams DJ, Kahler DJ, Yamaki M, Davidow L et al (2011) A functionally characterized test set of human induced pluripotent stem cells. Nat Biotechnol 29:279-286

71. Pera MF (2011) Stem cells: the dark side of induced pluripotency. Nature 471:46-47

72. Chin MH, Mason MJ, Xie W, Volinia S, Singer M, Peterson C, Ambartsumyan G, Aimiuwu O, Richter L, Zhang J et al (2009) Induced pluripotent stem cells and embryonic stem cells are distinguished by gene expression signatures. Cell Stem Cell 5:111-123

73. Kim K, Doi A, Wen B, Ng K, Zhao R, Cahan P, Kim J, Aryee MJ, $\mathrm{Ji}$ H, Ehrlich LI et al (2010) Epigenetic memory in induced pluripotent stem cells. Nature 467:285-290

74. Kim K, Zhao R, Doi A, Ng K, Unternaehrer J, Cahan P, Huo H, Loh YH, Aryee MJ, Lensch MW et al (2011) Donor cell type can influence the epigenome and differentiation potential of human induced pluripotent stem cells. Nat Biotechnol 29:1117-1119

75. Polo JM, Liu S, Figueroa ME, Kulalert W, Eminli S, Tan KY, Apostolou E, Stadtfeld M, Li Y, Shioda T et al (2010) Cell type of origin influences the molecular and functional properties of mouse induced pluripotent stem cells. Nat Biotechnol 28:848855

76. Ghosh Z, Wilson KD, Wu Y, Hu S, Quertermous T, Wu JC (2010) Persistent donor cell gene expression among human induced pluripotent stem cells contributes to differences with human embryonic stem cells. PLoS One 5:e8975

77. Hu Q, Friedrich AM, Johnson LV, Clegg DO (2010) Memory in induced pluripotent stem cells: reprogrammed human retinalpigmented epithelial cells show tendency for spontaneous redifferentiation. Stem Cells 28:1981-1991

78. Marchetto MC, Yeo GW, Kainohana O, Marsala M, Gage FH, Muotri AR (2009) Transcriptional signature and memory retention of human induced pluripotent stem cells. PLoS One 4:e7076

79. Guenther MG, Frampton GM, Soldner F, Hockemeyer D, Mitalipova M, Jaenisch R, Young RA (2010) Chromatin structure and gene expression programs of human embryonic and induced pluripotent stem cells. Cell Stem Cell 7:249-257

80. Ebert AD, Yu J, Rose FF Jr, Mattis VB, Lorson CL, Thomson JA, Svendsen CN (2009) Induced pluripotent stem cells from a spinal muscular atrophy patient. Nature 457:277-280

81. Marchetto MC, Carromeu C, Acab A, Yu D, Yeo GW, Mu Y, Chen G, Gage FH, Muotri AR (2010) A model for neural development and treatment of Rett syndrome using human induced pluripotent stem cells. Cell 143:527-539

82. Masimirembwa CM, Thompson R, Andersson TB (2001) In vitro high throughput screening of compounds for favorable metabolic properties in drug discovery. Comb Chem High Throughput Screen 4:245-263

83. Rodriguez-Antona C, Donato MT, Boobis A, Edwards RJ, Watts PS, Castell JV, Gomez-Lechon MJ (2002) Cytochrome P450 expression in human hepatocytes and hepatoma cell lines: molecular mechanisms that determine lower expression in cultured cells. Xenobiotica 32:505-520

84. Wilkening S, Stahl F, Bader A (2003) Comparison of primary human hepatocytes and hepatoma cell line Hepg2 with regard to their biotransformation properties. Drug Metab Dispos 31:1035-1042

85. Carpenter L, Carr C, Yang CT, Stuckey DJ, Clarke K, Watt SM (2012) Efficient differentiation of human induced pluripotent stem cells generates cardiac cells that provide protection following myocardial infarction in the rat. Stem Cells Dev 21(6):977986
86. Dambrot C, Passier R, Atsma D, Mummery CL (2011) Cardiomyocyte differentiation of pluripotent stem cells and their use as cardiac disease models. Biochem J 434:25-35

87. Greenbaum LE (2010) From skin cells to hepatocytes: advances in application of iPS cell technology. J Clin Invest 120:3102-3105

88. Jozefczuk J, Prigione A, Chavez L, Adjaye J (2011) Comparative analysis of human embryonic stem cell and induced pluripotent stem cell-derived hepatocyte-like cells reveals current drawbacks and possible strategies for improved differentiation. Stem Cells Dev 20:1259-1275

89. Rashid ST, Corbineau S, Hannan N, Marciniak SJ, Miranda E, Alexander G, Huang-Doran I, Griffin J, Ahrlund-Richter L, Skepper J et al (2010) Modeling inherited metabolic disorders of the liver using human induced pluripotent stem cells. J Clin Invest 120:3127-3136

90. Sullivan GJ, Hay DC, Park IH, Fletcher J, Hannoun Z, Payne CM, Dalgetty D, Black JR, Ross JA, Samuel K et al (2010) Generation of functional human hepatic endoderm from human induced pluripotent stem cells. Hepatology 51:329-335

91. Hanna J, Wernig M, Markoulaki S, Sun CW, Meissner A, Cassady JP, Beard C, Brambrink T, Wu LC, Townes TM et al (2007) Treatment of sickle cell anemia mouse model with iPS cells generated from autologous skin. Science 318:1920-1923

92. Wernig M, Zhao JP, Pruszak J, Hedlund E, Fu D, Soldner F, Broccoli V, Constantine-Paton $\mathrm{M}$, Isacson $\mathrm{O}$, Jaenisch $\mathrm{R}$ (2008) Neurons derived from reprogrammed fibroblasts functionally integrate into the fetal brain and improve symptoms of rats with Parkinson's disease. Proc Natl Acad Sci U S A 105:5856-5861

93. Schwartz SD, Hubschman JP, Heilwell G, Franco-Cardenas V, Pan CK, Ostrick RM, Mickunas E, Gay R, Klimanskaya I, Lanza R (2012) Embryonic stem cell trials for macular degeneration: a preliminary report. Lancet 379(9817):713-720

94. Nakatsuji N, Nakajima F, Tokunaga K (2008) HLA-haplotype banking and iPS cells. Nat Biotechnol 26:739-740

95. Yamanaka S (2009) A fresh look at iPS cells. Cell 137:13-17

96. Rizzino A (2010) Stimulating progress in regenerative medicine: improving the cloning and recovery of cryopreserved human pluripotent stem cells with ROCK inhibitors. Regen Med 5:799-807

97. Ichikawa H, Nakata N, Abo Y, Shirasawa S, Yokoyama T, Yoshie S, Yue F, Tomotsune D, Sasaki K (2012) Gene pathway analysis of the mechanism by which the Rho-associated kinase inhibitor Y-27632 inhibits apoptosis in isolated thawed human embryonic stem cells. Cryobiology 64:12-22

98. Li X, Krawetz R, Liu S, Meng G, Rancourt DE (2009) ROCK inhibitor improves survival of cryopreserved serum/feeder-free single human embryonic stem cells. Hum Reprod (Oxford, England) $24: 580-589$

99. Martin-Ibanez R, Stromberg AM, Hovatta O, Canals JM (2009) Cryopreservation of dissociated human embryonic stem cells in the presence of ROCK inhibitor. Current Proto Stem Cell Biol Chapter 1: Unit 1 C.8.

100. Takahashi K, Narita M, Yokura M, Ichisaka T, Yamanaka S (2009) Human induced pluripotent stem cells on autologous feeders. PLoS One 4:e8067

101. Mallon BS, Park KY, Chen KG, Hamilton RS, McKay RD (2006) Toward xeno-free culture of human embryonic stem cells. Int J Biochem Cell Biol 38:1063-1075

102. Vaajasaari H, Ilmarinen T, Juuti-Uusitalo K, Rajala K, Onnela N, Narkilahti S, Suuronen R, Hyttinen J, Uusitalo H, Skottman H (2011) Toward the defined and xeno-free differentiation of functional human pluripotent stem cell-derived retinal pigment epithelial cells. Mol Vis 17:558-575

103. Ma J, Guo L, Fiene SJ, Anson BD, Thomson JA, Kamp TJ, Kolaja KL, Swanson BJ, January CT (2011) High purity human 
induced pluripotent stem cell-derived cardiomyocytes: electrophysiological properties of action potentials and ionic currents. Am J Physiol Heart Circ Physiol 301:H2006-H2017

104. Salvagiotto G, Burton S, Daigh CA, Rajesh D, Slukvin II, Seay NJ (2011) A defined, feeder-free, serum-free system to generate in vitro hematopoietic progenitors and differentiated blood cells from hESCs and hiPSCs. PLoS One 6:e17829

105. Whitemarsh R, Strathman M, Chase L, Stankewicz C, Tepp W, Johnson E, Pellett S (2012) Novel application of human neurons derived from induced pluripotent stem cells for highly sensitive botulinum neurotoxin detection Biological Sciences: Applied Biological Sciences. Toxicol Sci 126(2):426-435

106. Hargus G, Cooper O, Deleidi M, Levy A, Lee K, Marlow E, Yow A, Soldner F, Hockemeyer D, Hallett PJ et al (2010) Differentiated Parkinson patient-derived induced pluripotent stem cells grow in the adult rodent brain and reduce motor asymmetry in Parkinsonian rats. Proc Natl Acad Sci U S A 107:15921-15926. doi:10.1073/pnas.1010209107

107. Park IH, Arora N, Huo H, Maherali N, Ahfeldt T, Shimamura A, Lensch MW, Cowan C, Hochedlinger K, Daley GQ (2008) Disease-specific induced pluripotent stem cells. Cell 134:877886. doi:10.1016/j.cell.2008.07.041

108. Soldner F, Hockemeyer D, Beard C, Gao Q, Bell GW, Cook EG, Hargus G, Blak A, Cooper O, Mitalipova M et al (2009) Parkinson's disease patient-derived induced pluripotent stem cells free of viral reprogramming factors. Cell 136:964-977. doi:10.1016/ j.cell.2009.02.013

109. Swistowski A, Peng J, Liu Q, Mali P, Rao MS, Cheng L, Zeng X (2010) Efficient generation of functional dopaminergic neurons from human induced pluripotent stem cells under defined conditions. Stem Cells 28:1893-1904. doi:10.1002/stem.499

110. Sanchez-Danes A, Richaud-Patin Y, Carballo-Carbajal I, Jimenez-Delgado S, Caig C, Mora S, Di Guglielmo C, Ezquerra M, Patel B, Giralt A et al (2012) Disease-specific phenotypes in dopamine neurons from human iPS-based models of genetic and sporadic Parkinson's disease. EMBO Mol Med. doi:10.1002/ emmm.201200215

111. Hotta A, Cheung AY, Farra N, Vijayaragavan K, Seguin CA, Draper JS, Pasceri P, Maksakova IA, Mager DL, Rossant J et al (2009) Isolation of human iPS cells using EOS lentiviral vectors to select for pluripotency. Nat Methods 6:370-376. doi:10.1038/ nmeth. 1325

112. Marchetto MC, Carromeu C, Acab A, Yu D, Yeo GW, Mu Y, Chen G, Gage FH, Muotri AR (2010) A model for neural development and treatment of Rett syndrome using human induced pluripotent stem cells. Cell 143:527-539. doi:10.1016/ j.cell.2010.10.016

113. Lemonnier T, Blanchard S, Toli D, Roy E, Bigou S, Froissart R, Rouvet I, Vitry S, Heard JM, Bohl D (2011) Modeling neuronal defects associated with a lysosomal disorder using patient-derived induced pluripotent stem cells. Hum Mol Genet 20:3653-3666. doi: $10.1093 / \mathrm{hmg} / \mathrm{ddr} 285$

114. Brennand KJ, Simone A, Jou J, Gelboin-Burkhart C, Tran N, Sangar S, Li Y, Mu Y, Chen G, Yu D et al (2011) Modelling schizophrenia using human induced pluripotent stem cells. Nature 473:221-225. doi:10.1038/nature09915

115. Jang J, Kang HC, Kim HS, Kim JY, Huh YJ, Kim DS, Yoo JE, Lee JA, Lim B, Lee J et al (2011) Induced pluripotent stem cell models from X-linked adrenoleukodystrophy patients. Ann Neurol 70:402-409. doi:10.1002/ana.22486

116. Jin ZB, Okamoto S, Osakada F, Homma K, Assawachananont J, Hirami Y, Iwata T, Takahashi M (2011) Modeling retinal degeneration using patient-specific induced pluripotent stem cells. PLoS One 6:e17084. doi:10.1371/journal.pone.0017084

117. Israel MA, Yuan SH, Bardy C, Reyna SM, Mu Y, Herrera C, Hefferan MP, Van Gorp S, Nazor KL, Boscolo FS et al (2012) Probing sporadic and familial Alzheimer's disease using induced pluripotent stem cells. Nature 482:216-220. doi:10.1038/nature10821

118. Raya A, Rodriguez-Piza I, Guenechea G, Vassena R, Navarro S, Barrero MJ, Consiglio A, Castella M, Rio P, Sleep E et al (2009) Disease-corrected haematopoietic progenitors from Fanconi anaemia induced pluripotent stem cells. Nature 460:53-59. doi:10.1038/nature08129

119. Carvajal-Vergara X, Sevilla A, D'Souza SL, Ang YS, Schaniel C, Lee DF, Yang L, Kaplan AD, Adler ED, Rozov R et al (2010) Patient-specific induced pluripotent stem-cell-derived models of LEOPARD syndrome. Nature 465:808-812. doi:10.1038/ nature 09005

120. Moretti A, Bellin M, Welling A, Jung CB, Lam JT, Bott-Flugel L, Dorn T, Goedel A, Hohnke C, Hofmann F et al (2010) Patientspecific induced pluripotent stem-cell models for long-QT syndrome. N Engl J Med 363:1397-1409. doi:10.1056/ NEJMoa0908679

121. Itzhaki I, Maizels L, Huber I, Zwi-Dantsis L, Caspi O, Winterstern A, Feldman O, Gepstein A, Arbel G, Hammerman H et al (2011) Modelling the long QT syndrome with induced pluripotent stem cells. Nature 471:225-229. doi:10.1038/nature09747

122. Tolar J, Xia L, Riddle MJ, Lees CJ, Eide CR, McElmurry RT, Titeux M, Osborn MJ, Lund TC, Hovnanian A et al (2011) Induced pluripotent stem cells from individuals with recessive dystrophic epidermolysis bullosa. J Invest Dermatol 131:848856. doi:10.1038/jid.2010.346

123. Sun N, Yazawa M, Liu J, Han L, Sanchez-Freire V, Abilez OJ, Navarrete EG, Hu S, Wang L, Lee A et al (2012) Patient-specific induced pluripotent stem cells as a model for familial dilated cardiomyopathy. Sci Transl Med 4:130ra147. doi:10.1126/ scitranslmed.3003552

124. Camnasio S, Carri AD, Lombardo A, Grad I, Mariotti C, Castucci A, Rozell B, Riso PL, Castiglioni V, Zuccato C et al (2012) The first reported generation of several induced pluripotent stem cell lines from homozygous and heterozygous Huntington's disease patients demonstrates mutation related enhanced lysosomal activity. Neurobiol Dis 46:4151. doi:10.1016/j.nbd.2011.12.042

125. Ghodsizadeh A, Taei A, Totonchi M, Seifinejad A, Gourabi H, Pournasr B, Aghdami N, Malekzadeh R, Almadani N, Salekdeh $\mathrm{GH}$ et al (2010) Generation of liver disease-specific induced pluripotent stem cells along with efficient differentiation to functional hepatocyte-like cells. Stem Cell Rev 6:622-632. doi:10.1007/s12015-010-9189-3

126. Zhang S, Chen S, Li W, Guo X, Zhao P, Xu J, Chen Y, Pan Q, Liu $X$, Zychlinski D et al (2011) Rescue of ATP7B function in hepatocyte-like cells from Wilson's disease induced pluripotent stem cells using gene therapy or the chaperone drug curcumin. Hum Mol Genet 20:3176-3187. doi:10.1093/hmg/ddr223

127. Schwartz RE, Trehan K, Andrus L, Sheahan TP, Ploss A, Duncan SA, Rice CM, Bhatia SN (2012) Modeling hepatitis C virus infection using human induced pluripotent stem cells. Proc Natl Acad Sci U S A 109:2544-2548. doi:10.1073/pnas.1121400109

128. Yusa K, Rashid ST, Strick-Marchand H, Varela I, Liu PQ, Paschon DE, Miranda E, Ordonez A, Hannan NR, Rouhani FJ et al (2011) Targeted gene correction of alphal-antitrypsin deficiency in induced pluripotent stem cells. Nature 478:391-394. doi:10.1038/nature10424

129. Lee G, Studer L (2011) Modelling familial dysautonomia in human induced pluripotent stem cells. Philos Trans R Soc Lond B Biol Sci 366:2286-2296. doi:10.1098/rstb.2011.0026

130. Liu J, Verma PJ, Evans-Galea MV, Delatycki MB, Michalska A, Leung J, Crombie D, Sarsero JP, Williamson R, Dottori M et al (2011) Generation of induced pluripotent stem cell lines from Friedreich ataxia patients. Stem Cell Rev 7:703-713. doi:10.1007/s12015-010-9210-x 